

\title{
Age, growth and reproduction of the gold band goatfish, Upeneus moluccensis off the Elkhoms coast of Libya
}

\author{
El-drawany, M.A. \\ Department of Zoology, Faculty of science, Zagazig University, Egypt \\ Email:samy_drawany@yahoo.com
}

\begin{abstract}
The age, growth parameters, spawning season, sex ratio, length at first sexual maturity and fecundity of the goldband goatfish, Upeneus moluccensis (Bleeker, 1855) caught in Elkhoms coasts of the Mediterranean Sea were investigated. It was found that, males constitute about $47.7 \%$ its population. Length-weight relationship of both sexes was illustrated as:

$$
\begin{array}{ll}
\mathrm{W}=0.01017 \mathrm{~L}^{3.01} & \text { for males and } \\
\mathrm{W}=0.00822 \mathrm{~L}^{3.09} & \text { for females }
\end{array}
$$

The age data derived from scale readings were used to estimate the growth parameters of the von Bertalanffy equation and the calculated parameters were:

$$
\mathrm{L} \infty=234.4 \mathrm{~mm}, \mathrm{~K}=0.2120 \text { and } \mathrm{t}_{\mathrm{o}}=-1.983 \text { for females }
$$$$
\mathrm{L} \infty=233.6 \mathrm{~mm}, \mathrm{~K}=0.2274 \text { and } \mathrm{t}_{\mathrm{o}}=-1.872 \text { for males and }
$$

It was found that the maximum age of males and females attained five years only. The second year age group was dominated the population. Otherwise, maturation of males and females occurred at a total length of about $11 \mathrm{~cm}$. The monthly values of the gonado-somatic index indicated that spawning of the studied fish take place mainly between May and July. The fecundity-length relationship designated that the fecundity is highly correlated with the fish length and expressed by the equation:
\end{abstract}

$$
\log F=0.0268+3.8120 \log L \quad(r=0.995) .
$$

\section{INTRODUCTION}

The goldband goatfish is a commercially important demersal fish species, living mostly on sand, muddy sand or gravel bottoms at depths ranging from 10 to $120 \mathrm{~m}$ (Golani, 1994 and Ozvarol et al., 2010). It is mainly a tropical and subtropical species, distributed along the western Indian Ocean and Red Sea (Ben-Tuvia and Golani, 1989 and Randall et al., 1993). The goldband goatfish Upeneus moluccensis (Bleeker, 1855) is a Lessepsian migrant fish which penetrates from Red Sea into the Mediterranean Sea through the Suez Canal (Golani and Ben-Tuvia, 1995). Lessepsian fish species such as Upeneus pori and Upeneus moluccensis, have been reported to be important in commercial fishing along the Libyan Mediterranean coast, since the Mediterranean continental shelf is relatively wide and its topographical structure is suitable for trawl fisheries (Ozvarol et al., 2010). The fishes inhabiting the Mediterranean Sea are well known on the global basis and are well documented (Whitehead et al., 1986; Fischer et al.,
1987 and Ismen, 2006). However on the regional scale, there are discontinuities in the knowledge, especially on the Lessepsian species of the northeastern Mediterranean Sea (Ismen, 2006).

Published information on the comprehensive biology and ecology of goldband goatfish along the Libyan coast of the Mediterranean Sea is scarce. However, in other coasts of the Mediterranean this fish species was studied satisfactorily by many researchers in recent years. The Upeneus moluccensis is a small fish not exceeding $25 \mathrm{~cm}$. in total length, but it is considered to be the most economic fish in Elkhoms coast due to its excellent quality of flesh and its moderate price in the local markets. In spite of this economic importance of this fish species, there is no information about its fisheries biology or its population dynamics in this region of Mediterranean Sea.

The present study provides information about the age, growth, sex ratio and reproduction of the goldband goatfish in Elkhoms coast of Libya, in the southern Mediterranean, as a contribution in the management of fishery exploiting stocks. 


\section{Materials and Methods}

A total of 426 goldband goatfish specimens were collected from the Elkhoms coasts between June 2006 and May 2007. Total length of each fish specimens was measured to the nearest millimeter, and whole body and weights were measured to the nearest gram. Age was determined by counting the annual rings on the scales using the scale micrometer. The body length-scale radius relationship was determined using the least square method. The back calculated lengths at the end of each year of life were obtained by using Lee's equation:

$$
\mathrm{L}_{\mathrm{n}}=(\mathrm{L}-\mathrm{a}) \mathrm{S}_{\mathrm{n}} / \mathrm{S}+\mathrm{a}
$$

Whereas $\left(L_{n}\right)$ is the calculated lengths at the end of $n$ year, ( $\mathrm{L})$ is the fish length, $\left(\mathrm{S}_{\mathbf{n}}\right)$ is the distance from the scale focus to the successive annuli, $(\mathrm{S})$ is the total scale radius and (a) is the intercept of the regression line with the $\mathrm{Y}$ axis.

The length-weight relationships were determined according to the allometric equation (Sparre et al., 1989): $\mathrm{W}=\mathrm{aL}^{\mathbf{b}}$

Where $\mathrm{W}$ is the total body weight gram,(L) the total length in $\mathrm{cm}$, and (a) and (b) are constants. Growth was expressed in terms of the von Bertalanffy equation (Beverton and Holt, 1957): $\mathrm{L}_{\mathbf{t}}=\mathrm{L}_{\infty}\left(1-\mathrm{e}^{-\mathbf{k}(\mathbf{t}-\mathrm{to})}\right)$

Where $(L \infty)$ is the asymptotic total length, $\left(\mathrm{L}_{\mathbf{t}}\right)$ the total length at age $(t),(K)$ is the growth curvature parameter and $\left(t_{\mathbf{0}}\right)$ is the theoretical age when fish would have been at zero total length. These parameters were estimated by means of von Bertalanffy plot (Sparre and Venema, 1992).

For the description of the sexual cycle of the goldband goatfish the sequence of gonad maturation was monthly observed and the spawning period was determined. The sex and maturity stage of each specimen were determined by visual and microscopic examination of the gonads. The seasonal evolution of the gonado somatic index was analyzed according to the formula: $\mathrm{GSI}=\mathrm{Wg} / \mathrm{W}$ X 100

Where $(\mathrm{Wg})$ is the gonad weight to the nearest 0.1 gram and (W) is the fish weight in gram. Length at first sexual maturity ( $\mathrm{L}_{\mathbf{m 5 0}}$ ) was estimated by King (1995) method.

The ovaries of 68 female goldband goatfish were cut longitudinally and stored in Gilson's fluid, which broke down the connective tissue for fecundity estimations. The egg numbers were estimated using the gravimetric method described by Bagenal (1978). The data were analyzed by least squares regression using $\log 10$ transformations (Ismen, 1995).

\section{RESULTS}

\section{Growth in Length:}

The relationship between the scale radii and the total fish lengths of $U$. moluccensis showed direct proportional one with high correlation presented in the following equations.

$$
\mathrm{L}=12.0089+13.718 \mathrm{~S} \quad \mathrm{n}=426 \quad \mathrm{r}^{2}=0.998
$$

From this equation the calculated lengths at the end of every year of life are computed by back calculations according to Lee's formula (1920):

$$
\mathrm{L}_{\mathrm{n}}=\mathrm{S}_{\mathrm{n}} / \mathrm{s}(\mathrm{L}-12.0089)+12.0089
$$

The results indicated that the studied fish reached five years old. The observed and the calculated total lengths at age were nearly similar in the five age groups (Tables $1 \& 2$ ). Upeneus moluccensis attained approximately $54 \%$ of its maximum size during the first year of life, (i.e. rapid growth occurs at the first year of life).

\begin{tabular}{|c|c|c|c|c|c|c|c|}
\hline \multirow{2}{*}{$\begin{array}{l}\text { Age } \\
\text { Group }\end{array}$} & \multirow{2}{*}{$\begin{array}{l}\text { Mean } \\
\text { Number }\end{array}$} & \multirow{2}{*}{$\begin{array}{l}\text { observe } \\
\text { Length }\end{array}$} & \multicolumn{5}{|c|}{ Back calculated lengths } \\
\hline & & & 1 & 2 & 3 & 4 & 5 \\
\hline I & 42 & 110 & 88.5 & & & & \\
\hline II & 76 & 134 & 99.7 & 128,1 & & & \\
\hline III & 44 & 152 & 98.6 & 130.6 & 149.6 & & \\
\hline IV & 36 & 169 & 98.8 & 132,0 & 149.9 & 166.5 & \\
\hline $\mathbf{v}$ & 25 & 181 & 98.5 & 131,8 & 150.4 & 169.0 & 179.7 \\
\hline \multicolumn{2}{|c|}{ Increment } & & 96.9 & 34.0 & 19.4 & 17.9 & 11.9 \\
\hline \multicolumn{2}{|c|}{$\%$ increment } & & 53.9 & 18.9 & 10.8 & 10.0 & 6.6 \\
\hline
\end{tabular}

Table 1: Back calculated lengths at the end of each year of life of female $\boldsymbol{U}$. moluccensis from the Elkhoms coasts

\begin{tabular}{|c|c|c|c|c|c|c|c|}
\hline \multirow{2}{*}{$\begin{array}{l}\text { Age } \\
\text { Group }\end{array}$} & \multirow{2}{*}{$\begin{array}{l}\text { Mean } \\
\text { Number }\end{array}$} & \multirow{2}{*}{$\begin{array}{l}\text { observed } \\
\text { Length }\end{array}$} & \multicolumn{5}{|c|}{ Back calculated lengths } \\
\hline & & & 1 & 2 & 3 & 4 & 5 \\
\hline I & 35 & 112 & 90.8 & & & & \\
\hline II & 70 & 138 & 96.0 & 133.1 & & & \\
\hline III & 40 & 155 & 993 & 130.8 & 150,2 & & \\
\hline IV & 35 & 172 & 101.6 & 131.0 & 151.5 & 168.2 & \\
\hline $\mathbf{v}$ & 23 & 185 & 104.6 & 127.8 & 148.2 & 168.7 & 182 \\
\hline \multicolumn{3}{|c|}{ Increment } & 98.4 & 32.3 & 19.2 & 18.6 & 13.8 \\
\hline \multicolumn{3}{|c|}{$\%$ increment } & 53.9 & 17.7 & 10.5 & 10.2 & 7.6 \\
\hline
\end{tabular}

Table 2: Back calculated lengths at the end of each year of male $U$. moluc censis from the Elkho ms coasts of

\section{Length - Weight relationship:}

The total length of Upeneus moluccensis ranged from 9 to 19 $\mathrm{cm}$. while the total weight ranged from $8.7 \mathrm{gm}$ to $69.3 \mathrm{gm}$. The length-weight relationships were separately calculated for females and males, and are presented in figures $(1 \& 2)$. The exponent (b) demonstrates an isometric growth as illustrated in the equations:

$$
\begin{aligned}
& \mathrm{W}=0.0082{ }^{\mathrm{X}} \mathrm{L} 3.09 \quad(\mathrm{r}=0.99) \text { for females and } \\
& \mathrm{W}=0.01017 \times \mathrm{L}^{3.01}(\mathrm{r}=0.99) \quad \text { for female. }
\end{aligned}
$$

Von Bertalanffy growth equation was applied to estimate the growth parameters $\left(\mathrm{K}, \mathrm{L}_{\infty}\right.$ and $\left.\mathrm{t}_{0}\right)$ of the studied species. The estimated von Bertalanffy growth parameters were

$\mathrm{L}_{\infty}=234.4 \mathrm{~mm}, \mathrm{~K}=0.2120$ and $\mathrm{t}_{\mathrm{o}}=-1.983$ for females

$\mathrm{L}_{\infty}=233.6 \mathrm{~mm}, \mathrm{~K}=0.2274$ and $\mathrm{t}_{\mathrm{o}}=-1.8715$ for males.

The U. moluccensis attained approximately $54 \%$ of its calculated maximum size during the first year of life. After completion of the first year, the annual growth rate ranged between 1 and $3 \mathrm{~cm}$. The maximum determined age was 5 for 
both sexes. Age group two was dominant in females $(34 \%)$ and males $(34.5 \%)$. In females, age group two was followed by age groups three $(19.7 \%)$, one $(18.8 \%)$, four $(16.1 \%)$ and five $(11.2 \%)$. In males, age group two was followed by age group three (19.7\%), one (17.2\%) and five (11.3\%).

Table (3) showing sex ratio of Upeneus moluccensis month wise.

\begin{tabular}{|c|c|c|c|c|c|c|c|}
\hline \multirow[t]{2}{*}{ Months } & \multirow{2}{*}{$\begin{array}{l}\text { No. of } \\
\text { Fish }\end{array}$} & \multicolumn{2}{|c|}{ Male } & \multicolumn{2}{|c|}{ Female } & \multicolumn{2}{|c|}{ Ratio } \\
\hline & & No. & $\%$ & No. & $\%$ & male & female \\
\hline January & 38 & 18 & 8.87 & 20 & 8.97 & 1 & 1.11 \\
\hline February & 35 & 17 & 8.37 & 18 & 8.07 & 1 & 1.05 \\
\hline March & 40 & 19 & 4.36 & 21 & 9.42 & 1 & 1.10 \\
\hline April & 37 & 17 & 8,37 & 20 & 8.97 & 1 & 1.18 \\
\hline May & 39 & 18 & 8.87 & 21 & 9.42 & 1 & 1.17 \\
\hline Jun & 34 & 16 & 7.88 & 18 & 8.07 & 1 & 1.13 \\
\hline July & 38 & 18 & 8.87 & 20 & 8.97 & 1 & 1.11 \\
\hline August & 37 & 17 & 8.37 & 20 & 8.97 & 1 & 1.17 \\
\hline September & 32 & 15 & 7.39 & 17 & 7.62 & 1 & 1.13 \\
\hline October & 31 & 17 & 8.37 & 14 & 6.28 & 1 & 0.82 \\
\hline November & 34 & 15 & 7.39 & 19 & 8.52 & 1 & 1.26 \\
\hline December & 31 & 16 & 7.88 & 15 & 6.73 & 1 & 0.93 \\
\hline Total & 426 & 203 & 99.99 & 223 & 100.0 & 1 & 1,096 \\
\hline
\end{tabular}

The mean sex ratio around all the studied period of female to male was 1.00:1.096. The number of female to male was given monthly and presented in table (3). All the monthly samples contained more females than males, except October and December. Examination of the male and female maturity stages indicated that males and females of U. moluccensis matured at about $11 \mathrm{~cm}$ total lengths, one year old (Fig. 3). The GSI results revealed that fish spawning occurred at July in this region of the Mediterranean Sea, when the GSI for both sexes reached its highest level (Fig. 4). However, the presence of mature individuals in August indicates that reproduction may continue at a reduced rate during summer.

Fecundity of Upeneus moluccensis was ranged from 11395 eggs for $11.5 \mathrm{~cm}$ to 64940 eggs for $18 \mathrm{~cm}$. It was tightly correlated with the female as expressed in the following equation of fecundity-length relationship:

$\log \mathrm{F}=0.0268+8.8120$ where $\quad \mathrm{r}=0.995$
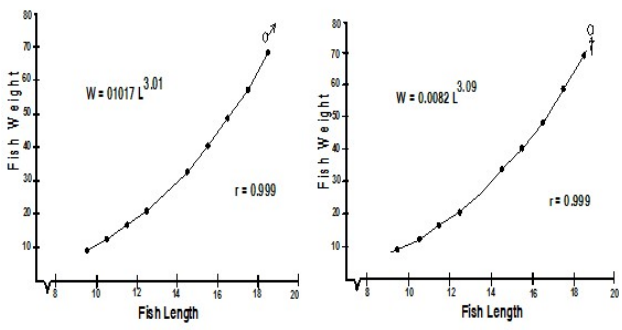

Fig.(1) length weight relationship of male Upeneus moluccensis

Fig.(2) length weight relationship of female Upeneus moluccenst

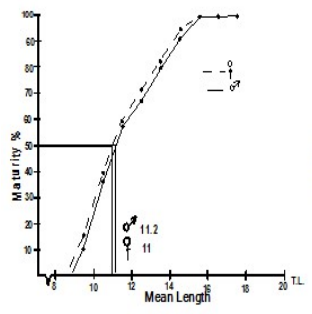

Fig (3) Length at first maturity of both sex of Upeneus moluccensis

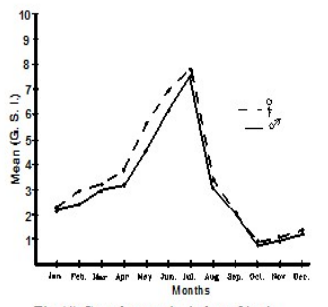

Fig (4) Gonadosomatic index of both sexes of Upeneus moluccensis



Fig. (5) Relationship between absolute fecundity and total length of Upeneus moluccensis

\section{Discussion}

The passage of Lessepsian fish species to the Mediterranean has affected on the ecosystem balance of the species in the Mediterranean. Even though there are not sufficient studies conducted, it was observed that the Lessepsian species which entered and rapidly colonized the Mediterranean competed with the indigenous species in terms of sharing the food and the habitat (Ismen, 2006).

The goldband goatfish is commercially important for the Mediterranean fisheries in Libya. The results of the growth rate in the first year of the goldband goatfish caught in Elkhoms coast of Libya reported in the present study are in agreement with those reported by Kaya et al (1999) in south Aegean coasts of Turkey, Ismen (2005) in Iskenderun Bay, the Eastern Mediterranean and Ozvarol et al (2010) in the gulf of Antalya (Turkey). It was found that the first annulus is formed at a length of $11.2 \mathrm{~cm} ; 11 \mathrm{~cm}$ and $11 \mathrm{~cm}$ respectively. However, Torcu (1995) in Iskenderun Bay, stated that the first annulus of this fish species was formed at $8.2 \mathrm{~cm}$. The mean annual growth rate in the present study for 1-5-years old ranged between $1.2-3.4 \mathrm{~cm}$ and $1.4-3.2 \mathrm{~cm}$ for females and males respectively (Tables $1 \& 2$ ). Growth was rapid in both sexes for the first year and declined gradually over subsequent years. Torcu (1995) reported that the mean annual growth rate for 1-5 years old of the same fish was about $1.9 \mathrm{~cm}, 1.7 \mathrm{~cm}$, $1.3 \mathrm{~cm}$ and $1.4 \mathrm{~cm}$, respectively. Mean while Kaya et al. (1999) stated that this mean annual growth rate for 1-6-years old fish was about $1.9 \mathrm{~cm}, 1.7 \mathrm{~cm}, 1.3 \mathrm{~cm}$ and $1.4 \mathrm{~cm}$, for females and males respectively.

Table (4): The von Bertalanffy growth parameters of the goldband goatfish Upeneus moluccensis from different localities. 


\begin{tabular}{|c|c|c|c|c|c|}
\hline Author & Location & Lo & $\mathrm{K}$ & to & $\varphi$ \\
\hline Bingel et al.(1993) & Mediterranean 2 & 25.6 & 0.621 & $-0,270$ & 6,01 \\
\hline El-Drawany.(1995) & Red sea & 24.3 & 0.228 & -1.523 & 4.15 \\
\hline Kaya etal. (1999) & Mediterranean 2 & 26.0 & 0.110 & -3.770 & 4,31 \\
\hline Ismen. $_{\text {. }}(2005)$ & Mediterranean & 25.2 & 0.197 & -1.002 & 4,83 \\
\hline Ozvarol et al (2010). & Mediterranean & 25.6 & 0.136 & -3.828 & $\cdots$ \\
\hline $\begin{array}{l}\text { Present study } \\
\text { for } \hat{\jmath}\end{array}$ & Mediterranean & 23.4 & 0.227 & -1.872 & 4.05 \\
\hline $\begin{array}{l}\text { Present study } \\
\text { for } 9\end{array}$ & Mediterranean & 23.4 & 0.212 & -1.983 & 4.07 \\
\hline
\end{tabular}

These differences in growth rates might be attributed to different bio-ecological conditions. The absence of a 0 age group in the samples was probably due to the selectivity of the cod-end used in the trawl nets.

From the given data in the table (4) it was found that there are no significant difference between the overall growth performances of the goldband goat fish sampled from the different regions in the north and eastern Mediterranean. The values of these parameters are $L \infty=24.3 \mathrm{k}=0.228 \mathrm{t}_{0}=-$ 1.532 for the Gulf of Suez Red sea (El-drawany, 1995) and $\mathrm{L} \infty=25.2 \mathrm{k}=0.197 \mathrm{t}_{0}=-1.002$ for Iskenderun Bay, the north-eastern Mediterranean (Ismen, 2005). Goncalves et al (2003) reported that the estimated von Bertalanffy growth parameters may vary according region, and year. Recently, Cicek and Avsar (2011) decided that, the major driving force in population fluctuation is recruitment variability year by yea. The female to male ratio of the goat fish in the present study was 1: 1.096 is similar to that derived by Ismen (2005) for same species but was differed from that in the north-eastern Mediterranean (2.7 and 3.4) (Torcu, 1995 and Kaya et al., 1999). Seasonal variations in the sex ratio may be due to the differences in the length (or age) of sexual maturity (Ismen, 2006).

In the present investigation it was found that length-weight relationship is nearly the same for both sexes, the functional regression $b$ values (3.09) for female and (3.01) for males of the goldband goatfish was differed from those given by Anonymous (1993), Torcu (1995) and Kaya et al. (1999) . Anonymous (1993) indicated that the value of exponent $b$ of the length weight relationship for combined sexes was 3.30 while Torcu (1995) stated that the $b$ value of the length weight relationship for pooled data was 3.21. Also Kaya et al. (1999) reported that the $b$ value estimated for males and females were 3.15 and 3.35 , respectively. This is because the functional regression $b$ value is directly related to the weight affected by different ecological factors such as temperature, food supply, spawning conditions and habitat characteristics.

The GSI data revealed that, the spawning of goldband goatfish fish occurred at July, when the GSI for both sexes reached its highest level (Fig. 4). However Ismen (2005) stated that this fish species spawns at June. However, the presence of mature individuals in September indicated that the reproduction may continue at a lesser rate during summer. While Kaya et al (1999) reported that the spawning season of goldband goatfish was between August and October during their study in south Aegean and Mediterranean.

Table 5: Length weight relationships of $U$. moluccensis recorded by some authors in different regions

\begin{tabular}{|c|c|c|c|c|}
\hline $\begin{array}{l}\text { Authors } \\
\text { Anonymous Mama } \\
(1993 \text { ) }\end{array}$ & $\begin{array}{l}\text { Regions } \\
\text { lara Aegean sea }\end{array}$ & $\begin{array}{l}\text { Sex } \\
\text { combined }\end{array}$ & $\begin{array}{c}a \\
0.000004\end{array}$ & $\begin{array}{l}\mathrm{b} \\
3.30\end{array}$ \\
\hline Torcu (1995) Nor. E & East,Mediter. & combined & 1.0554 & 3,21 \\
\hline El-Drawany Red S & & Male & 0.01130 & 3.009 \\
\hline (1995) & & Female & 0.10700 & 3.028 \\
\hline \multirow{2}{*}{\multicolumn{2}{|c|}{ Kaya et al (1999) Mediterranean }} & Male & 0.01501 & 3.150 \\
\hline & & Female & 0.00607 & 3.352 \\
\hline $\begin{array}{l}\text { Taskavak\& East } \\
\text { Bileceoglu (2001) }\end{array}$ & Mediterranean co & combined & 0.000013 & 3.021 \\
\hline \multirow[t]{2}{*}{ Ismen (2005) } & Northem east & Male & 0.0118 & 2.99 \\
\hline & Mediterranean & Female & 0.0117 & 3.00 \\
\hline \multirow[t]{2}{*}{ Ozvarol et al. (2010) } & Gulf of Anatalya & Male & 0,010 & 2.99 \\
\hline & Turkey & Female & 0.010 & 3.025 \\
\hline \multirow[t]{2}{*}{ Presnt study } & Northem & Male & 0.1017 & 3.01 \\
\hline & Mediterranean & Female & 0.0082 & 3.09 \\
\hline
\end{tabular}

Sexual maturity of both sexes of $U$. moluccensis in Elkhoms coasts of Libya was with the first age group. This is similar to the findings of Kaya et al. (1999) and Ozvarol et al. (2010) whose reported that the sexual maturity of the fish was also in the first age group in south Aegean and Mediterranean. Nonetheless, Ismen (2005) found that the individual of both sexes mature for the first time after the second year of life.

The number of eggs (fecundity) of the present studied fish is ranged between 11.395 and 64.940 for lengths of 11.5 and 18 $\mathrm{cm}$. It is tightly related to the fish length where (r) is equal to 0.995. However, Torcu (1995) showed that the fecundity of U. moluccensis varies between 19.714 and 64.452, and the amount of eggs increases with age.

\section{References}

Anonymous (1993): Final report of demersal fisheries resource survey in the Republic of Turkey. Sanyo-TechnoMarine Inc., by Japan Intern. Cooperation Agency, 254 p.

Bagenal, T.B. (1978): Methods for Assessment of Fish Production in Fresh Waters. T.B. Bagenal (Editor): IBP Handbook. No. 3, Blackwell Scientific Publications, London, pp. 166-178.

Ben-Tuvia, A. and Golani, D. (1989): A new species of goatfish (Mullidae) of the genus Upeneus from the Red Sea and the eastern Mediterranean. Isr. J. Zool. 36 pp 103-112.

Bingel, F.; Ozsoy, E. and Unluata, U. (1993): A Review of the State of the Fisheries and the Environment of the Nor the eastern Mediterranean (Northern Levantine Basin). Studies and Reviews, General Fisheries Council for the Mediterranean. No. 65. Rome, FAO, 74 P.

Beverton, R.J.H and Holt, S.J. (1957): On the dynamics of exploited Fish populations. UK. Min. Agric. Fish., Fish Invest., 19, $53 \mathrm{P}$.

Bleeker, P. (1855): Zesde bijdrage tot de kennis der ichthyolgische fauna van Amboina. Nat.Tijdscr. Nederlandsch-Indie, Vol. 8, pp. 391-434. 
Cicek, E.; Avsar, D.; Yeldan, H. And Ozutok, M. (2002): Population characteristics of the por's goatfish Upeneus pori (Ben- Tuvia \& Golani, 1989). Inhabiting in Babadillimanı Bight (Northeastern Mediterranean-Turkey. Workshop on Lessepsian Migration, 20-21 July 2002,Gokceada Turkey, pp. 92-99

Cicek, E. and Avsar, D. (2011): Age, growth and mortality of Upeneus pori (Ben-Tuvia and Golani,1989) off the karats coasts of Iskenderun Bay. J. of Anim. And Vet. Adv.10 (7), pp 878-882.

El-Drawany, M.A. (1995): Comparative biological studies on two fish species of Family Mullidae. Ph.D. Thesis, Faculty of Science, Zagazig University.

Fischer, W.; Bauchot, M. L.; Schneider, M. (1987): Fiches FAO dÕidentification des especes pour les besoins de la peche. (Rev.1) Mediterraneee et mer Noire. Rome, FAO, vol.2 pp. 761-1530.

Goncalves, J.M.; Bentes, L.; Coelho, R.; Correia, C. and Lino, P.G. (2003): Age and growth, maturity, mortality and yield-per-recruit for tow band bream (Diplodus vulgaris) from the south coast of Portugal. Fish. Res, 62, pp. 349-359.

Golani, D. (1990): Environmentally induced meristic changes in Lessepsian fish migrants, a comparison of source and colonizing populations. Bull. L" Institute Ocean. Monaco (special issue) 7, pp. 143-152.

Golani, D. (1994): Niche separation between colonizing and indigenous goatfishes (Mullidae) of the Mediterranean coast of Israel. J. Fish Biol., 45, pp. 503-513.

Golani, D. and Ben-Tuvia, A. (1995): Lessepsian migration and the Mediterranean fisheries of Israel. In: Arman trout, N.B. (ed.) Conditions of the World's Aquatic Habitats. Proc. World Fish. Congr. Theme I. Oxford \& IBH Pub. Co. Pvt. Ltd., New Delhi, pp. 279-289.

Holden, M. J. and Raitt, D. F. S. (1974): Manual of fisheries science. Part:2-Methods of resource investigation and their application. FAO Fish. Tech. Rap. (115): Rev.1, 214 P.

Ismen, A. (1995): Fecundity of whiting, Merlangius merlangus euxinus, on the Turkish Black Sea coast. Fisheries Research, 22, pp. 309-318.

Ismen, A. (2005): Age, growth and reproduction of the Goldband Goatfish, Upeneus moluccensis (Bleeker, 1855), Iskenderun Bay, the Eastern Mediterranean, Turk J. Zool., 20, $p p: 301-309$.

Ismen , (2006) : Growth and reproduction of por's goatfish (Upeneus pori Ben-Tuvia and Golani, 1989) in Iskenderun Bay, the Eastern Mediterranean. Turk. J. Zool. 30, pp. 91-98

Kaya, M.; Benli, H.A.; Katagan, T. and OzaydÝn, O. (1999): Age, growth, sex-ratio, spawning season and food of golden banded goatfish, U. moluccensis Bleeker (1855) from the Mediterranean and south Aegean coasts of Turkey. Fisheries Research. 41, pp. 317-328.

King, M. (1995): Fisheries Biology, Assessment and Management. Blackwell Science Ltd., Oxford.

Lee, R.M. (1920): A review of the methods of age and growth determination by means of scales. Fishery Investigations, London, Series, 11(4), pp. 2-32.
Lee, C.K.C. (1974): The reproduction, growth and survival of $U$. moluccensis in relation to the commercial fishery in Hong Kong. Hong Kong Fish. Bull. 4, pp. 17-32.

Randall,J.E.; Bauchot M.L. and Gueze, P. (1993): Upeneus japonicus (Houttuyu), asenior synonym oh the Japanese goatfish U. japonicus (Temminck et Schlegel). Jap. J. Ichthyol. pp. 301-305.

Sangum. L.; Akamaka, E. and Akar, M. (2007): Weight length relationships for 39 fish species from the North-Eastern Mediterranean Coast of Turkey. Turk. J. of Fisheries \& Aquat. scien. 7,pp. 37-40

Sparre, P.; Ursin, E. and Venema, S.C. (1989): Introduction to Tropical Fish Stock Assessment. Part 1Manual, FAO Fish Tech. Pap., No. 306, pp. 337- 346.

Taşkavak, E. and Bilecenoğlu, M., (2001): Length-weight relationships for 18 Lessepsian (Red Sea) immigrant fish species from the eastern Mediterranean coasts of Turkey. J. Mar. Biol. Ass. U.K. 81, pp: 895-896.

Torcu, H. (1995): Indo-Pacific species inhabited Mediterranean and south Aegean coast of Turkey and studies on biology and ecology of goldband goatfish, Upeneus moluccensis (Bleeker, 1855) and lizardfish, Saurida undosquamis (Richardson, 1848). Selcuk University, Inst. Science, PhD. Thesis, Konya 168 P.(in Turkish).

Torcu, H. and Mater, S., (1997): An investigation on biological aspects of the golden-banded goat fish Upeneus moluccensis (Bleeker, 1859) living in Fethiye and Mersin Gulf, In the proceedings of Mediterranean Fisheries Congress, 9-11 April 1996, pp: 545-554

Torcu, $M$ and M. Mater, (2000): Lessepsian fishes spreading along the coast the Mediterranean and the southern Aegean sea of Turkey. Turk. J. Zool. 241,pp : 139-148

Whitehead, P.J.P.; Bauchot, M.-L.; Hureau, J.C.; Nielsen, J. and Tottonese, E. (1986): Fishes of the North-Eastern Atlantic and the Mediterranean. Vol. II. UNESCO, Paris. pp: 511-100.

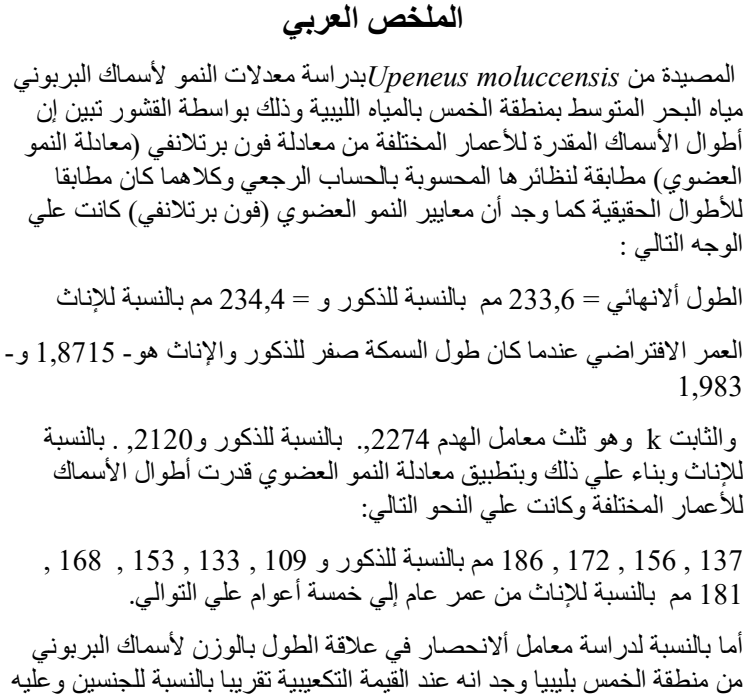


فان هذا النوع من الأسماك متماثل النمو أي انه لا يوجد أي تغير في الثنكل كلما

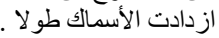

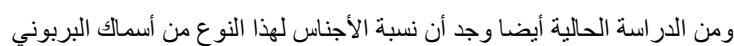

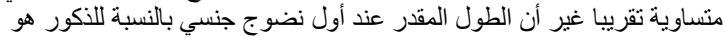
11 سم وبالنسبة للإناث هو 11,2 سم .

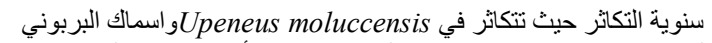
الفترة من مايو وحتى نهاية شهر يوليو في مع ملاحظة أن قمة موسم التكاثر في شهر لئر يوليو.

كما تم در اسة خصوبة هذا النوع من اسماك البربوني وتبين أن الخصوبة المطلقة

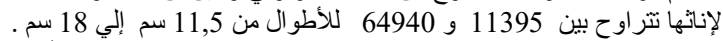

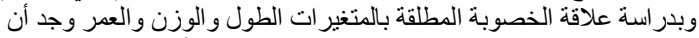

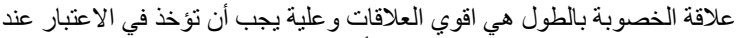

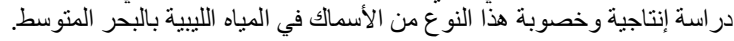

